\title{
Stealth regulation: biological circuits with small RNA switches
}

\author{
Susan Gottesman \\ Laboratory of Molecular Biology, National Cancer Institute, Bethesda, Maryland 20892, USA
}

So you think you finally understand the regulation of your favorite gene? The transcriptional regulators have been identified; the signaling cascades that regulate synthesis and activity of the regulators have been found. Possibly you have found that the regulator is itself unstable, and that instability is necessary for proper regulation. Time to look for a new project, or retire and rest on your laurels? Not so fast-there's more. It is rapidly becoming apparent that another whole level of regulation lurks, unsuspected, in both prokaryotic and eukaryotic cells, hidden from our notice in part by the transcription-based approaches that we usually use to study gene regulation, and in part because these regulators are very small targets for mutagenesis and are not easily found from genome sequences alone. These stealth regulators, operating below our radar, if not that of the cell, are small regulatory RNAs, acting to control the translation and degradation of many messengers. These RNAs can be potent and multifunctional, allowing new signaling pathways to cross-regulate targets independently of the transcriptional signals for those targets, introducing polarity within operons, and explaining some puzzles in well-studied regulatory circuits.

The importance of small regulatory RNAs was first appreciated in the elegant studies of plasmid-encoded antisense RNAs. The few apparently unusual cases of noncoding regulatory RNAs encoded in the bacterial chromosome has expanded over the last decade, and the role such RNA regulators play in both stimulating and inhibiting gene expression has been firmly established. As genome sequences have become available for many bacteria, it has become possible to search for additional members of this regulatory family, and, eventually, to begin to understand how they act at the molecular level.

Simultaneously, researchers in eukaryotic systems were discovering the wonders of RNAi, a cellular strategy for protecting itself from RNA invaders, in which small double-stranded RNA molecules cause destruction of homologous messages. The discovery that developmental mutants in Caenorhabditis elegans define genes for two small RNA translational regulators, called small

E-MAIL susang@helix.nih.gov; FAX (301) 496-3875.

Article and publication are at http://www.genesdev.org/cgi/doi/10.1101/ gad.1030302. temporal RNAs (stRNAs) or microRNAs, and that these RNAs are processed by some of the same protein cofactors as is RNAi, have put regulatory RNAs in the spotlight in eukaryotes as well. Recent searches have confirmed that flies, worms, plants, and humans all harbor significant numbers of small RNAs likely to play regulatory roles.

Along with the rapid expansion in RNAs doing interesting things, has come a proliferation of nomenclature. Noncoding RNAs (ncRNA) has been used recently, as the most general term (Storz 2002). Among the noncoding RNAs, the subclass of relatively small RNAs that frequently act as regulators have been called stRNAs (small temporal RNAs, eukaryotes) and sRNAs (small RNAs, prokaryotes), among others. Here, I will refer to the regulatory RNAs, which should be considered a subset of the ncRNAs.

I review here the range of regulatory RNAs that have been identified and how they can be found, what we know about how they work, drawing lessons from the plasmid antisense molecules, and how they transduce regulatory signals. These stealthy RNAs may be the final level of unexpected regulatory circuitry in all of those systems we thought we were beginning to understand; now that we know they are there, we have some hope of understanding what it is they do and how they do it.

\section{What regulatory RNAS do we know about and how do we find more?}

Small regulatory RNAs are small, and possibly as a result, have not generally been found in mutant hunts. Therefore, realizing that they are there at all has been the first challenge. Maybe not surprisingly, the small, wellstudied genomes of plasmid and bacteriophage were the first place these molecules were noted and investigated. The plasmid-encoded RNA regulators are generally encoded by the antisense strand for their target gene or transcript and, thus, are complementary to it over many nucleotides (nt). The ground-breaking and still fairly unique example in this field is the regulation of ColE1 replication by RNAI, elegantly studied by Tomizawa and coworkers (for review, see Eguchi et al. 1991; Zeiler and Simons 1996; discussion below). This 108-nt RNA interacts with the RNA primer for DNA replication, leading to a decrease in the frequency with which the RNA 
primer extends into a DNA primer and, therefore, lowering plasmid copy number. The use of antisense RNA to control plasmid copy number is widespread in both gram-positive and gram-negative organisms; in many of these plasmids, it is synthesis of the replication protein that is subject to negative regulation rather than the replication primer itself. A second set of plasmid-encoded RNA-based regulatory systems are the antitoxin components of post-segregational killing (PSK) modules or addiction systems (Fig. 2, below; for review, see Gerdes et al. 1997; Engelberg-Kulka and Glaser 1999). These systems help ensure plasmid stability by acting as lethal timers, killing cells that have lost the encoding plasmid. Toxin synthesis or activity is sequestered by an unstable antitoxin; when new mRNA synthesis ceases with loss of the plasmid from the cell and the unstable antitoxin decays, the toxin is free to kill the cell. For one set of such toxin/antitoxin systems, including the well-studied hok/sok system from ColE1 (for review, see Gerdes et al. 1997), the unstable antitoxin is a small RNA that inhibits, by a complicated series of events, the synthesis of the toxin. In other cases, the antitoxin is an unstable protein, degraded by the ATP-dependent cytoplasmic proteases. In addition to these plasmid systems, antisense RNAs have been found to regulate phage immunity and growth, as well as transposition, again using RNAs encoded by the antisense strand of the target gene (for review, see Wagner and Simons 1994; Zeiler and Simons 1996).

What about the bacterial host itself? As of 1999, about a dozen small RNAs encoded by the Escherichia coli chromosome had been identified. Almost all of these were found either in searches for stable small RNAs or serendipitously-from phenotypes of multicopy plasmids or by identification of unexpected transcripts near genes of interest (for review, see Wassarman et al. 1999; Gottesman et al. 2001; Wassarman 2002). This set of 12 RNAs in E. coli has expanded to $>50$ over the last two years, as a result of a concerted effort in a number of laboratories to define methods for finding small RNAs in genomes (summarized in Table 1). The searches in E. coli utilized conservation at both the sequence and structural level (covariation suggesting the existence of stems; Rivas et al. 2001; Wassarman et al. 2001) and prediction of orphan promoters and rho-independent terminators to define small $(<300-n t)$ transcripts that contain no ORFs (Argaman et al. 2001; Chen et al. 2002; Table 1). All of these searches focused on intergenic regions (defined as the sequences between ORFs), and all but Chen et al. (2002) used conservation as at least one criteria. Thus, these searches will have missed anything encoded within genes, on either the sense or antisense strand, and are less likely to have found small RNAs that are not conserved. Nonetheless, it seems likely that a bacterial genome such as E. coli contains in the range of 50-100 small RNAs, not thousands.

In archaea, small noncoding RNAs have been found recently by their high GC content in high AT organisms (Klein et al. 2002; Schattner 2002) and by isolation and sequencing of small RNAs (Tang et al. 2002; Table 1).
Some of these RNAs resemble the snoRNAs that act as guides for tRNA and rRNA modification in eukaryotes, but a substantial number appear to be unique. The function of these newly described ones remains unknown; presumably some are regulatory RNAs.

In eukaryotes, searches for small RNAs have been motivated by the recognition of two small RNAs, lin-4 and let-7, as critical regulators of development in C. elegans. Methods were designed to purify RNAs with similarity to these molecules (Lagos-Quintana et al. 2001, 2002; Lau et al. 2001; Lee and Ambros 2001; Reinhart et al. 2002). This approach has successfully found dozens of similar molecules, called microRNAs, in C. elegans, Drosophila, Hela cells, mouse tissues, and Arabidopsis (summarized in Table 1); these molecules are frequently found to be embedded in a larger (65-70 nt) inverted repeat structure, and to depend on processing by the RNAse III homolog Dicer for maturation. Like lin-4 and let-7, it is expected that these will act as translational repressors. Essentially all of these RNAs appear to be encoded outside of ORFs; some of the RNAs identified are conserved among fairly disparate species. In these organisms, conservation of intergenic regions can also be used as an indicator of the presence of structured small RNAs (Lee and Ambros 2001); approaches that depend on finding promoters and terminators are unlikely to be as useful in the near future. The other class of small RNAs that might have been identified in these searches are the interfering RNAs, or RNAi; little evidence for such double-stranded RNAs were found, supporting the idea that although microRNAs do regulatory jobs in the cell, RNAi is primarily used to protect the cell from invaders. A broader search for somewhat larger RNAs in the mouse brain yielded multiple new guide RNAs as well as many of unknown function (Huttenhofer et al. 2001). Although it is not yet possible to make an accurate estimate of the numbers of small RNAs in a eukaryotic genome, those found thus far in nonexhaustive searches suggest many hundreds are likely.

It is clear that what has been learned thus far will simplify future searches for these previously elusive regulators. Using the characteristics of the most interesting of the currently known small RNAs, increasingly sophisticated searches for new members of the same or related classes can be designed. Conservation of sequence and structure are an excellent pointer to small RNAs, and stem-loops seem to be a universal characteristic of either the small RNAs or their precursors. Direct isolation of RNA of the expected sort (size, structure of the ends) also works, but again depends on what one defines as expected, and when the RNA is expressed.

Protein cofactors can also be used to isolate specific classes of RNA; in bacteria, the RNA chaperone Hfq binds to and can be immunoprecipitated with multiple small RNAs (Wassarman et al. 2001). Antibodies to components of a protein complex implicated in RNA processing and ribonucleoprotein assembly also immunoprecipitate multiple small RNAs, some with the characteristics of the microRNAs discussed above (Mourelatos et al. 2002). 
Table 1. Schemes for detecting small RNAs in genomes

\begin{tabular}{|c|c|c|c|c|}
\hline Organism & Search criteria & Comments/Predictions & Confirmed RNAs & Reference \\
\hline E. coli & $\begin{array}{l}\text { 1) Conserved sequence } \\
\text { in IG } \\
\text { 2) Stem-loops and/or } \\
\text { microarray signal }\end{array}$ & & $\begin{array}{l}16 \text { sRNAs, } 6 \text { ORFs/ } \\
60 \text { tested }\end{array}$ & (Wassarman et al. 2001) \\
\hline E. coli & Conserved structure in IG & 275 candidates & $11 / 49$ tested & (Rivas et al. 2001) \\
\hline E. coli & $\begin{array}{l}\text { 1) Orphan promoters, } \\
\text { terminators in IG } \\
\text { regions } \\
\text { 2) Conserved sequences }\end{array}$ & & $14 / 23$ tested & (Argaman et al. 2001) \\
\hline E. coli & $\begin{array}{l}\text { Orphan Promoters } \\
\text { terminators at } \\
\text { distances }>45,<350 \\
\text { apart }\end{array}$ & $\begin{array}{l}227 \text { initial candidates: } \\
144 \text { possible sRNA }\end{array}$ & $\begin{array}{l}\text { 7/8 tested novel; } 6 \\
\text { others found } \\
\text { previously }\end{array}$ & (Chen et al. 2002) \\
\hline M. jannaschi & $\begin{array}{c}(\mathrm{G}+\mathrm{C}) \% \text { and } \mathrm{CG} \\
\text { dinucleotides }\end{array}$ & tRNAs, rRNAs found & $\begin{array}{l}19 \text { candidates; none } \\
\text { tested }\end{array}$ & (Schattner 2002) \\
\hline M. jannaschi & High GC regions & tRNAs, rRNAs found & $4 / 9$ tested & (Klein et al. 2002) \\
\hline \multirow[t]{2}{*}{ P. furiosus } & $\begin{array}{l}\text { High GC, conserved } \\
\text { sequence }\end{array}$ & & $4 / 8$ tested & (Klein et al. 2002) \\
\hline & $\begin{array}{l}\text { Conserved structure in } \\
\text { IG }\end{array}$ & & $4 / 17$ tested & (Klein et al. 2002) \\
\hline A. fulgidus & $\begin{array}{l}\text { Transcript size } \\
\quad(50-500 \mathrm{nt})\end{array}$ & $\begin{array}{l}\text { 36/86 in known } \\
\text { classes (snoRNAs) }\end{array}$ & $\begin{array}{l}86 \text { (50 of unknown } \\
\text { function) }\end{array}$ & (Tang et al. 2002) \\
\hline Mouse & $\begin{array}{l}\text { Transcript size } \\
\quad(50-500 \mathrm{nt})\end{array}$ & $\begin{array}{l}\text { 113/206: snoRNAs } \\
\text { 26/201: in genes }\end{array}$ & $\begin{array}{l}201 \text { ( } 57 \text { of unknown } \\
\text { function) }\end{array}$ & (Huttenhofer et al. 2001) \\
\hline \multirow[t]{2}{*}{ C. elegans } & $\begin{array}{l}\text { Conservation, stem-loop } \\
\text { structure, in IG }\end{array}$ & 40 candidates & $3 / 40$ tested & (Lee and Ambros 2001) \\
\hline & $\begin{array}{l}\text { Transcript Size }(22 \mathrm{nt}) \\
\text { conserved stem-loop }\end{array}$ & 38 candidates & $13 / 13$ tested & (Lee and Ambros 2001) \\
\hline C. elegans & $\begin{array}{c}\text { Transcript size }(18-26 \\
n t), 5^{\prime} \mathrm{P}, 3^{\prime} \text { OH } \\
\text { Homology/proximity }\end{array}$ & $\begin{array}{l}\text { Stem-loop precursors } \\
3 \text { found near others }\end{array}$ & 55 new microRNAs & (Lau et al. 2001) \\
\hline $\begin{array}{l}\text { D. melanogaster } \\
\text { HeLa cells }\end{array}$ & Transcript size (19-25 nt) & $\begin{array}{l}\text { Stem-loop precursors } \\
\text { for microRNAs }\end{array}$ & $\begin{array}{l}16 \text { novel microRNAs } \\
21 \text { novel microRNAs }\end{array}$ & $\begin{array}{l}\text { (Lagos-Quintana et al. 2001) } \\
\text { (Lagos-Quintana et al. 2001) }\end{array}$ \\
\hline Mouse & Transcript size (19-25 nt) & $\begin{array}{l}\text { Tissue-specific } \\
\text { expression; } \\
\text { Stem-loop } \\
\text { precursors }\end{array}$ & 34 novel microRNAs & (Lagos-Quintana et al. 2002) \\
\hline Arabidopsis & $\begin{array}{l}\text { Transcript size }(22 \mathrm{nt}) \\
5^{\prime}-\mathrm{P}, 3^{\prime} \mathrm{OH} \text { ends }\end{array}$ & $\begin{array}{l}\text { MicroRNAs; } \\
\text { Stem-loop } \\
\text { precursors; } \\
2 \text { without stem-loop }\end{array}$ & $\begin{array}{l}\text { 16/16 microRNAs; } \\
1 / 2 \text { others }\end{array}$ & (Reinhart et al. 2002) \\
\hline
\end{tabular}

All small RNAs listed here as confirmed were either predicted by the means indicated and then confirmed by Northern blot or were originally detected as a transcript. Purely computational approaches make significantly larger predictions of possible small RNAs; some of these predictions have been tested, and those that are confirmed are presented here. Others predicted but not confirmed may include conserved secondary structure elements in intergenic regions associated with mRNAs (for instance, terminator/antiterminator sequences).

One approach that has only begun to be explored is the use of microarrays to detect small RNAs (Wassarman et al. 2001); this approach will obviously require the presence of intergenic regions on such microarrays, as well as tests under appropriate expression conditions. A recent set of microarray experiments under a variety of conditions identifies some of the previously found and some potential additional small RNAs in intergenic regions of E. coli (Tjaden et al. 2002). Approaches to finding small RNAs have been reviewed elsewhere recently (Eddy 2001, 2002; Storz 2002).

These searches make it clear that noncoding regula- tory RNAs are ubiquitous, reasonably abundant, and often well conserved. The next challenge is understanding how these frequently unrecognized, but key participants, in regulatory pathways act.

\section{How do regulatory RNAs regulate?}

Are there any general rules that we can extract from what we know thus far? Can we discern why a regulatory RNA is used in preference to a protein? At the mechanistic level, most of these regulatory RNAs act in one of two general ways, both of which use the nature of 
nucleic acid structure and pairing to provide the major source of specificity.

The most obvious use of an RNA regulator takes advantage of its ability to pair with another polynucleotide strand, usually a second RNA. By such pairing, it can change the structure of the target RNA and/or block or recruit proteins (including the ribosome) to the target RNA (Fig. 1A). Thus, it can act as either a positive or negative regulator of translation and/or stability of mRNAs. The degree of pairing and the details of the effects on target structure and activity provide a wealth of variations on regulatory possibilities (Fig. 1A). Regulatory signals primarily act at the level of synthesis of the regulatory RNA, although in many cases the kinetics of transcription relative to the kinetics of RNA-RNA interaction may be critical. This review is focused on this general class of regulators, explored in more detail below.

The second type of activity identified for some regulatory RNAs are as molecular decoys, in which the regulatory target is a protein rather than another RNA. Frequently, in these cases, the regulatory RNA structure and/or sequence resembles that of the protein's alternative target; thus, the regulatory RNA may compete for the protein binding to that target. The clearest case of such a molecular decoy is the regulation of CsrA activity by the regulatory RNA, CsrB (Fig. 1B; for review, see Romeo 1998). CsrA binds to the upstream region of the mRNA of a number of genes involved in glycogen storage and energy metabolism in E. coli; homologs are involved in pathogenesis in the plant pathogen, Erwinia carotovora, and other Erwinia species. CsrA binding prevents ribosome binding, down-regulating translation of these genes and increasing the instability of the target mRNA (Baker et al. 2002). The sequence within the 5' UTR of the mRNA that is recognized and bound by CsrA is also found in the CsrB regulatory RNA-18 times! This 366-nt RNA includes a repeating sequence with a core of $7 \mathrm{nt}$ that bind CsrA; many of these repeats are at the top of stem-loops. Thus, CsrB can (and does) bind 18 copies of CsrA. When CsrB is absent, CsrA-dependent inhibition of translation is much more pronounced (Gudapaty et al. 2001). Exactly what regulatory switches affect whether CsrA binds CsrB or its targets and when CsrB is made is just beginning to be explored (Suzuki et al. 2002).

A second regulatory RNA that has been suggested to act as a molecular decoy, again from the E. coli literature, is 6S RNA (Wassarman and Storz 2000). 6S, sonamed because of its observed size in the centrifugation conditions under which it was first isolated and characterized, remained a well-conserved, abundant, and stable RNA without a function until the recent studies of Wassarman and Storz (2000). They demonstrated that 6S RNA binds specifically and exclusively to one protein, RNA polymerase. In bacteria, RNA polymerase core binds to alternative $\sigma$ factors, subunits that give it promoter specificity, to form different holoenzymes. 6S RNA specifically recognizes the holoenzyme containing $\sigma 70$, the major vegetative $\sigma$ factor. The 6S RNA structure may mimic DNA at the promoter, competing with binding of RNA polymerase to $\sigma 70$-specific promoters. This should result in down-regulating the activity for $\sigma$ 70 promoters relative to promoters recognized by other $\sigma$ factors. In vivo, such a switch between a $\sigma$ 70-dependent promoter and a second promoter in the same gene that uses the RpoS $\sigma$ factor was seen. Phenotypes of mutants devoid of $6 \mathrm{~S}$ are relatively mild, suggesting that either the critical condition for $6 \mathrm{~S}$ action has not yet been identified, and/or that this is only one of multiple mechanisms for modulating RNA polymerase action and promoter selection.

One odd but fascinating small RNA that doesn't fit either of the categories above is tmRNA, an RNA that serves as both a functional-specific tRNA and a short messenger (for review, see Karzai et al. 2000; Gillet and Felden 2001). It is recruited to stalled ribosomes, in which it adds an 11-amino-acid tail to the stalled polypeptide, ending with a stop codon, and thereby releasing both the ribosome and the tagged polypeptide (Keiler et al. 1996; Ueda et al. 2002). The tagged polypeptide is efficiently recognized and degraded by the Clp and FtsH proteases (Gottesman et al. 1998; Herman et al. 1998). The major role of tmRNA is as a quality control mechanism. However, a role in regulation has been proposed; a low level of natural tagging and, therefore, degradation of
Figure 1. Categories of regulatory RNA action. (A) Regulatory RNA as antisense. Many small RNAs act as antisense regulators, pairing with a target, usually a messenger RNA, to change its behavior. In $E$. coli, many, if not all, such regulatory RNAS use the Hfq protein to stimulate pairing (discussed in text). In all of the figures, the regulatory RNAs are shown in red. $(B)$ Regulatory RNA as molecular mimic. One example of another class of small RNAs is shown at right. This is modeled on the CsrA/CsrB system, in which the protein CsrA is a translational inhibitor; inhibition is relieved by binding of multiple molecules of CsrA by CsrB (for review, see Romeo 1998).
A

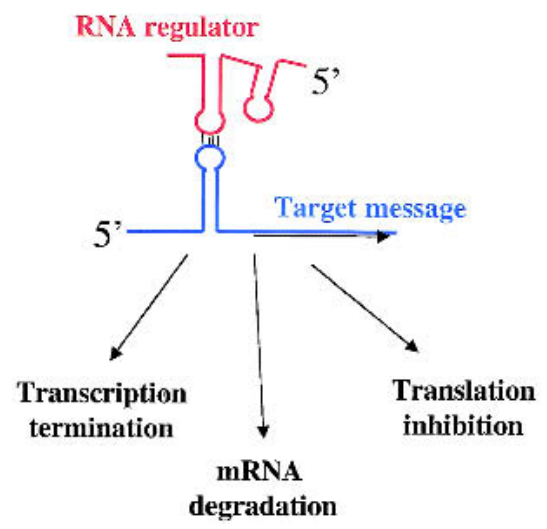

B

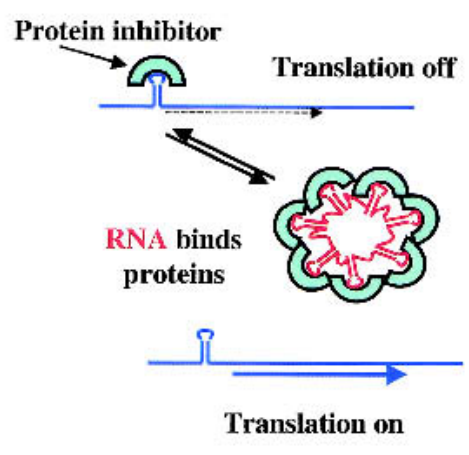


some regulatory proteins may help to poise the system to be particularly responsive to inducing signals (Abo et al. 2000). tmRNA, widespread in prokaryotes, has not yet been identified in eukaryotes; presumably other processes serve the same purpose in those cells (Karzai et al. 2000).

Not considered further in this review are many additional roles of RNAs, including 4.5S RNA, part of the protein secretion apparatus, ribozymes, in which the RNA is the active site moiety for a ribonucleoprotein complex, the guide RNAs used to direct RNA modifications (Kiss 2002), Xist RNAand other large RNAs implicated in chromosome silencing (for review, see Eddy 2001; Storz 2002), or some additional uses of small RNAs, for instance, the phi29 RNA that directs phage DNA packaging (Chen et al. 2000).

\section{Antisense and anti-antisense regulation by small RNAs}

Figure 1A diagrams, in the most general terms, the varied consequences for mRNA activity and stability caused by a small RNA able to pair with it. The small regulatory RNA can be encoded either by the complementary strand of the target mRNA, as for phage and plasmid antisense RNAs, or by a free-standing gene, encoded far from the target genes. The resulting changes in biological activity can include changes in the processing and degradation of the target message, changes in the formation of terminators, and changes in the efficiency of translation.

What are the questions that we would like to be able to answer to understand the action of such a transacting regulatory RNA on its target? Following are some general questions investigators in this field have pursued and will be pursuing in the years to come. Answers to some of these questions are available for a few well-studied cases and may suggest principles for understanding the many cases in which we know very little.
(1) Does pairing occur and is it required? Is there complementarity between regulatory RNA and target? How much is essential? Can mutations in the regulatory RNA which abolish pairing be suppressed by secondary mutations in the target RNA that restore pairing?

(2) How is pairing initiated? How does this inter-RNA pairing compete with other intra-RNA pairing alternatives? Do RNA chaperones or other proteins play a critical role in allowing this initial pairing? How do transcription and translation of the target affect pairing?

(3) What are the structural and kinetic consequences that follow initial pairing? Are there further required RNA interactions? At what stage does the process become irreversible?

(4) What are the molecular outcomes of the interaction? Is the stable interaction of RNA with target itself sufficient for the biological effect, or is there an active and necessary recruitment of other factors? Is the small RNA consumed or used catalytically during the interaction?

\section{Pairing for specificity and activity: lessons} from plasmids

Transcripts from opposing strands of the same DNA piece are expected to base pair, fulfilling the first requirement outlined above; this is the situation for the antisense RNAs that regulate plasmid replication and toxinantitoxin systems (Fig. 2). In most of these cases, the critical test of the importance of such pairing-the behavior of mutations and compensating mutations that first disrupt and then restore pairing-has been done.

Plasmid regulatory RNAs appear to initiate pairing by the interaction of loops in the regulatory RNA and target. These initial kissing complexes, the first step in the relationship, are generally short (6-8-nt loops); interactions from more than a single pair of loops may be necessary to stably initiate the process, which rapidly ma-

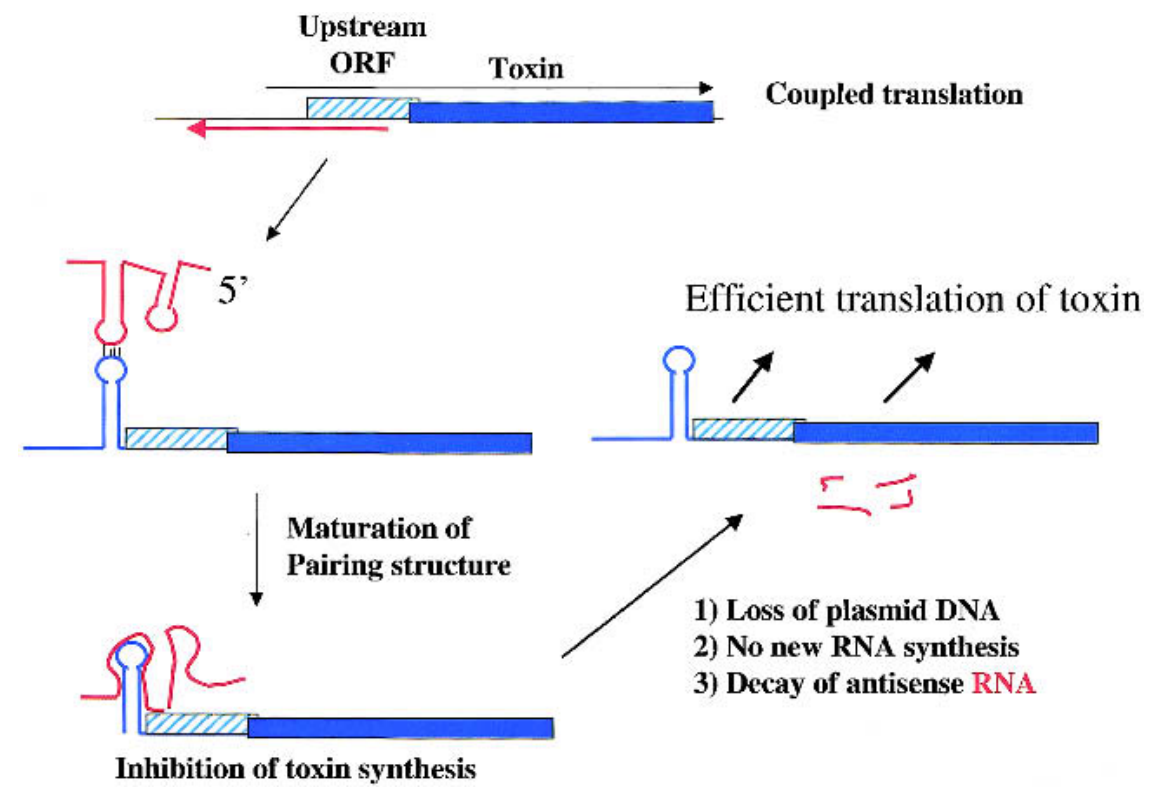

Figure 2. Antisense RNA regulating toxin synthesis. In this highly simplified version of the action of the hok/sok posttranscriptional killing system of plasmid $\mathrm{R} 1$, antisense RNA, encoded on the opposite strand, pairs with regions necessary for translation of an upstream ORF. Translation of the toxin gene requires translation of the upstream ORF. Once new antisense RNA ceases to be made, its decay releases the toxin mRNA for efficient translation. A similar arrangement is found in the regulation of many plasmid replication proteins (see text and Table 2). See Gerdes et al. (1997) for a more detailed discussion of this system. 
tures into a more extended interaction (Fig. 2). It has been suggested that loops with a particular sequence motif (YUNR, Pyrimidine-U-N-Purine), found in many of the plasmid and phage systems, are particularly efficient for promoting these initial interactions (Franch et al. 1999a). Maturation can include both extension of the region of pairing initiated at the loops and interactions between other regions of regulatory RNA and target RNA. However, a number of studies have suggested that full base pairing throughout the complementary region is not necessary for biological activity; much shorter interactions, initiated by interactions of loop sequences and maturing into partially complementary structures are sufficient (Siemering et al. 1994; Malmgren et al. 1997; Franch et al. 1999b; for review, see Wagner and Brantl 1998).

Whereas the plasmid-based antisense RNAs resemble each other in the nature of their initial pairing interactions, they differ rather drastically in the consequences of pairing (Table 2). In the first example listed in Table 2, replication of plasmid colE1 begins with an RNA primer. Once the primer RNA reaches a certain length, the formation of a persistent RNA/DNA hybrid leads to RNase $\mathrm{H}$ cleavage. It is the cleaved RNA that serves as a primer for DNA synthesis (for review, see Eguchi et al. 1991). Interaction of the antisense regulator, RNAI, with the primer interferes with formation of the RNA/DNA hybrid, therefore preventing plasmid replication. The kinetic window for RNA I interaction is relatively short; after the primer RNA becomes a certain length and RNAse $\mathrm{H}$ cleavage has occurred, RNA I can no longer inhibit. Therefore, anything that affects the kinetics of the interaction serves as a critical regulatory step. The balance between RNA I inhibition and primer maturation is believed to be poised at the correct level for ColE1 copy number control by a variety of characteristics of the system and is stimulated by the action of a protein cofactor, Rom (or Rop in related systems; Tomizawa and Som 1984).
Kinetics of interaction between the antisense RNA and the target is also critical for the second example in Table 2, copy number control of Staphylococcal plasmid pT181. In this case, synthesis of the replication initiator protein, RepC, is negatively regulated by antisense RNA pairing, again initiating with kissing structures. The 5' UTR of the RepC message contains sequences for mutually exclusive antiterminator and terminator stemloops, as is found in the attenuators of amino acid synthesis operons in Salmonella and E. coli. However, in this case, the transacting regulatory RNA, ctRNA, rather than ribosomes translating a leader peptide, regulates the efficiency of terminator formation. By binding to sequences in the antiterminator, ctRNA prevents antiterminator stem-loop formation, allowing formation of the terminator and down-regulating RepC synthesis and copy number (Novick et al. 1989). Once the antiterminator forms and transcription proceeds beyond the terminator, it is too late for the regulatory RNA to act. This control circuit is reminiscent of a chromosomally encoded attenuation system, widely used in gram-positive bacteria to modulate the synthesis of tRNA synthetases and amino acid synthesis genes when the cell is starving for a given amino acid (for review, see Henkin 1996). A complex 5' UTR, capable of forming both an antiterminator stem-loop and a mutually exclusive terminator, is in these genes, and the choice between antiterminator or terminator is also regulated by a small RNA-in this case, a specific uncharged tRNA. The cognate uncharged tRNA for the amino acid relevant to a given gene interacts with the 5' UTR to change folding, decreasing terminator formation and increasing synthesis from the gene. It is tempting to wonder whether these plasmid and host systems are evolutionally related, although regulation is in opposite directions /stimulating termination for the plasmid regulator and stimulating antitermination for the bacterial genes).

Many other plasmid-encoded antisense RNAs act at the level of translation, either directly affecting transla-

Table 2. Representation mechanisms of plasmid and phage antisense control

\begin{tabular}{|c|c|c|c|}
\hline Plasmid & $\begin{array}{l}\text { Antisense } \\
\text { RNA }\end{array}$ & General Mechanism & Reference \\
\hline Plasmid ColE1 copy number control & RNAI & $\begin{array}{l}\text { Block persistent RNA/DNA primer, } \\
\text { decrease DNA initiation }\end{array}$ & (Eguchi et al. 1991) \\
\hline pT181, pIP501 copy number control & & $\begin{array}{l}\text { Promote transcription termination of } \\
\text { repC mRNA }\end{array}$ & (Novick et al. 1989) \\
\hline Plasmid RI copy number control & CopA & $\begin{array}{l}\text { Inhibition of upstream ORF } \\
\text { translation, coupled to repA } \\
\text { translation }\end{array}$ & (Blomberg et al. 1992) \\
\hline RI post-segregational killing & Sok & $\begin{array}{l}\text { Inhibition of translation of upstream } \\
\text { ORF, coupled to translation of Hok } \\
\text { toxin }\end{array}$ & (Gerdes et al. 1997) \\
\hline Plasmid pAD1 post-segregational killing & RNAII & $\begin{array}{l}\text { Inhibition of toxin translation by } \\
\text { changes in upstream RNA folding } \\
\text { of toxin message }\end{array}$ & (Greenfield et al. 2001) \\
\hline Phage P1, P7, P4 immunity & $\mathrm{C} 4(\mathrm{P} 1, \mathrm{P} 7), \mathrm{CI}(\mathrm{P} 4)$ & $\begin{array}{l}\text { Inhibition of translation of upstream } \\
\text { ORF, causing transcription } \\
\text { termination, interfering with } \\
\text { antirepressor synthesis }\end{array}$ & $\begin{array}{l}\text { (Heinrich et al. 1995; } \\
\quad \text { Lindqvist et al. 1993) }\end{array}$ \\
\hline
\end{tabular}


tion of the replication protein, or, more commonly, inhibiting translation of an upstream ORF whose translation is coupled to that of the replication protein. Similar circuits govern some of the toxin/antitoxin systems. Two examples are listed in Table 2. The CopA antisense RNA of plasmid R1 inhibits translation of an upstream ORF, called Tap; translation of RepA depends on translation of Tap (Blomberg et al. 1992; for review, see Brantl 2002). In the toxin/antitoxin hok/sok system, sok inhibits translation of the upstream mok ORF, coupled with hok toxin translation (Gerdes et al. 1997; Fig. 2). In IncB and other plasmids, a pseudoknot in the upstream ORF $(\mathrm{RepB})$ is needed for translation of the RepA protein. Antisense RNA inhibits translation of RepB, and translation of this ORF is necessary for pseudoknot formation and, therefore, for RepA translation (Wilson et al. 1994; Asano et al. 1999).

Why are these upstream sequences and extra ORFs in the regulatory circuit? Possibly an extra element changes either the tightness of the regulation or adds other points of regulation by adding an additional factor. However, as no function for these upstream ORFs as proteins has been discerned, possibly the inclusion of a place saver of this sort is easier to evolve with a tight antisense RNA. Because these plasmid systems use an overlapping antisense RNA, the fewer constraints on the sense strand, in terms of the function of the protein, the better. The nature of its initiation signals and the rate of its translation may be more important than the sequence of the protein. An exception that makes a similar point is a gram-positive toxin/antitoxin system encoded by plasmid pAD1, listed in Table 2. In this case, no upstream ORF has been detected, but sequences in the 5' UTR lead to poor translation of the toxin. The antisense RNA overlaps and influences the structure of these sequences (Greenfield et al. 2001), so antisense is still working at a distance. The final example in Table 2, the immunity systems of phages $\mathrm{Pl}, \mathrm{P} 7$, and $\mathrm{P} 4$, combine elements found in a number of these plasmid systems - coupling translation of an upstream ORF to transcription termination, and, therefore, down-regulating synthesis of an antirepressor (see Table 2).

\section{How do bacterial and eukaryotic regulatory RNAs compare with the plasmid antisense RNAs?}

The growing number of bacterial and eukaryotic regulatory RNAs that have been described recently are not generally made from the antisense strand of their target, and may, in fact, have multiple targets. Therefore, unlike the plasmid antisense RNAs discussed above, they are not capable of completely base pairing with their targets. Are the plasmid-encoded antisense RNAs qualitatively different in their mode of action from the small regulatory RNAs encoded in the bacterial chromosome? Whereas none of the bacterial or eukaryotic regulatory RNAs have yet been studied in the detail in which the plasmid RNAs have been, the information thus far available suggests that there are enough parallels for the lessons from the plasmid studies to be useful. Hopefully, some of these lessons may also, eventually, extend to the eukaryotic regulatory RNAs.

Many of the characteristics of the initial complexes seen with the plasmid regulatory RNAs are mirrored in the interactions of bacterial regulatory RNAs. The three bacterial RNAs in which interaction with a target has been most fully explored are discussed below. In each of these cases, two regions of 7-9 bp of complementarity are present, and mutations in either region interfere with the activity of the regulatory RNA. These regions can be separated by large distances within the linear sequence of the small RNA. Whether other interactions also are required is less clear. As with the plasmid RNA regulators, the outcome of pairing by the bacterial small RNAs varies. Some small RNAs stimulate translation rather than inhibiting it. One inhibits translation within an operon without leading to mRNA degradation. Yet others stimulate mRNA degradation.

One clear distinction between the plasmid and bacterial cases is that the plasmid regulatory RNAs are dedicated to regulation of a single target. This is not so for the regulatory RNAs encoded by the bacterial and eukaryotic chromosomes. Possibly, for an RNA to act on a single target, evolution of an overlapping transcript saves space and ensures coevolution (and, therefore, continued specificity) for these extrachromosomal and frequently mobile elements. The implications of this for evolution of mutually compatible plasmids has been noted before (Asano and Mizobuchi 2000). For the bacterial regulators, both the small RNAs and the targets appear to be unusually well conserved in related bacteria (Wassarman et al. 2001), presumably a reflection of the need to maintain pairing and, therefore, regulation during evolution.

Almost all of the bacterial small RNAs that work by pairing have also been shown to require Hfq in vivo, a protein with sequence and structural similarity to eukaryotic Sm proteins involved in RNA splicing (Schumacher et al. 2002). Hfq binds the small RNAs as well as their targets and, in vitro, stimulates their pairing (Moller et al. 2002a; Zhang et al. 2002). This chaperone-like function may be necessary to prevent alternative RNA conformations and because of the limited complementarity of RNA regulator and target. As expected for a chaperone-like protein, as Hfq appears to be, is the observation that the Hfq requirement can be partially bypassed when the small RNA is abundant enough (Sledjeski et al. 2001). It is worth noting that the kissing complex that forms the first step in ColE1 replication control is also stimulated by a protein cofactor, Rom, with no observed sequence similarity to Hfq (Tomizawa and Som 1984). Thus, even a system with extensive possible pairing can benefit from a protein cofactor. Whether there are protein components for the other plasmid systems is unclear; no plasmid-encoded functions have been identified, but the possible role of Hfq or other host-encoded RNA chaperones remains to be tested.

One of the best studied of the bacterial RNA regulators is OxyS. OxyS RNA has multiple effects (Table 3). Negative regulation of $f h l A$, a transcription factor, requires an interaction between OxyS and a region overlapping the 
Table 3. Regulatory signal cascades for bacterial regulatory RNAs

\begin{tabular}{|c|c|c|c|c|c|}
\hline Signals & Regulator & Small RNA & Targets & Regulatory logic & Reference \\
\hline oxidative stress & OxyR & OxyS & $\begin{array}{l}\text { fhlA }(-) \\
\operatorname{rpos}(-) \text { mutagenesis }(-)\end{array}$ & Repair system priorities & (Altuvia et al. 1997) \\
\hline low temperature & None identified & DsrA & $\begin{array}{l}\operatorname{rpos}(+) \\
\text { hns }(-)\end{array}$ & $\begin{array}{l}\text { Low temperature } \\
\text { requirement for } \\
\text { RpoS? }\end{array}$ & $\begin{array}{l}\text { (Repoila and } \\
\quad \text { Gottesman 2001) }\end{array}$ \\
\hline cell surface stress & $\mathrm{R} \operatorname{csC} / \mathrm{R} \operatorname{csB}$ & RprA & $\operatorname{rpoS}(+)$ & Unknown & (Majdalani et al. 2002) \\
\hline $\begin{array}{l}\text { carbon source } \\
\text { preferences }\end{array}$ & $\mathrm{cAMP} / \mathrm{CRP}$ & spot 42 & galK (-) & $\begin{array}{c}\text { Fine-tuning of carbon } \\
\text { source metabolism }\end{array}$ & (Moller et al. 2002b) \\
\hline low iron & Fur $(-)$ & RyhB & $\begin{array}{l}\operatorname{sdh}(-) \\
\operatorname{ftn}(-) \\
\text { fumA }(-) \\
\text { others }(-)\end{array}$ & Intracellular iron use & $\begin{array}{l}\text { (Massé and Gottesman } \\
\text { 2002) }\end{array}$ \\
\hline
\end{tabular}

ribosome-binding site of $f h l A$. This 7-bp complementarity between the $3^{\prime}$ end of OxyS and the ribosome-binding site of the fhlA target gives only partial repression; repression is significantly stronger when a second 9-bp complementary region is included. This second region is $41 \mathrm{nt}$ distant from the first on the $f h l A$ structural gene, and it pairs with a region near the $5^{\prime}$ end of OxyS, fully $75 \mathrm{nt}$ away from the $3^{\prime}$ end of OxyS that mediates the first pairing. In vitro tests of RNA structure show that both sets of oxyS and fhlA sequences are in loop structures, allowing the formation of kissing complexes (Altuvia et al. 1998; Argaman and Altuvia 2000).

Two small RNAs, DsrA and RprA, positively regulate rpoS translation by an extended interaction with the upstream message for RpoS; this interaction in turn relieves an inhibitory pairing between this upstream message and the RpoS ribosome-binding and initiation region (Fig. 3). DsrA contains a region of $23 \mathrm{nt}$, of which 21 nt can base pair with the target messenger RNA; this is one of the most extended stretches of complementarity found for bacterial regulatory RNAs. Whereas DsrA mutations in some positions have more profound effects than others for the regulation of rpos translation, complementarity in two separate regions (A pairing to $\mathrm{A}^{\prime}$ and $\mathrm{B}$ to $\mathrm{B}^{\prime}$ in Fig. 3) have been shown to be critical for DsrA action (Majdalani et al. 1998). Region A of DsrA is believed to be unpaired (Lease and Belfort 2000); region B is in a 5-nt loop (Fig. 3). The structure of the target rpoS message has not been examined, but can be modeled into stem-loops that suggest the possibility of kissing complexes with DsrA (S. Gottesman, unpubl.). The second small RNA that positively regulates $r p o S$, RprA, also is known to pair to the $\mathrm{A}^{\prime}$ and $\mathrm{B}^{\prime}$ regions of the rpoS message. However, in RprA, the A and B regions are separated into two stretches, with $9 \mathrm{nt}$ of apparently unpaired RNA between them (Majdalani et al. 2002). No direct structural information is thus far available for RprA, but in one of two alternative structures predicted by com-
Figure 3. Positive regulation by small RNAs. RpoS translation is occluded by a hairpin that includes sequences from the upstream message (Brown and Elliott 1997). rbs, ribosome-binding site; ATG, starting codon of RpoS coding region. At least two small RNAs, DsrA and RprA, are able to increase translation by pairing with the upstream region of the hairpin (Majdalani et al. 1998, 2002). Pairing in vivo has been demonstrated for mutations in regions $\mathrm{A} / \mathrm{A}^{\prime}$ and $\mathrm{B} / \mathrm{B}^{\prime}$, as described in the text. The structure of DsrA is based on Lease and Belfort (2000); the structure of RprA is a computer prediction (MFOLD; Devereux et al. 1984). A similar example of positive regulation by release of an inhibitory hairpin has been described for RNA III stimulation of $\alpha$-toxin synthesis in $S$. aureus (Morfeldt et al. 1995).
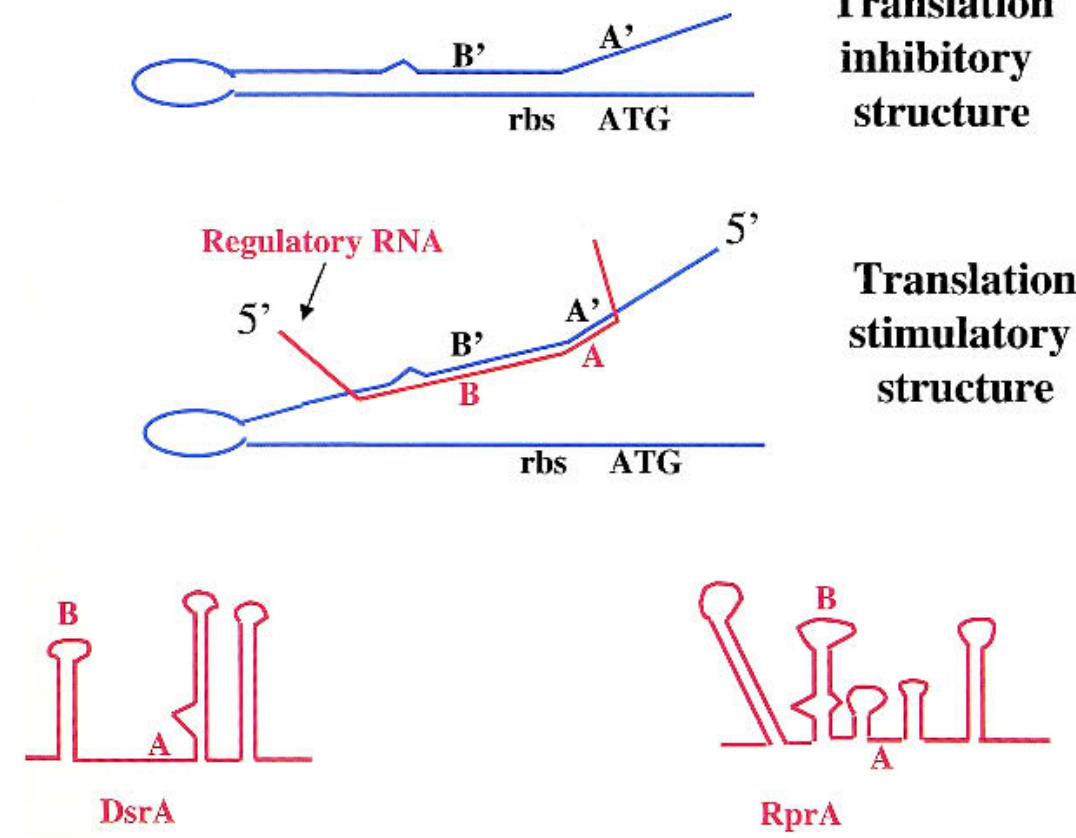

\section{Translation stimulatory structure}

DsrA

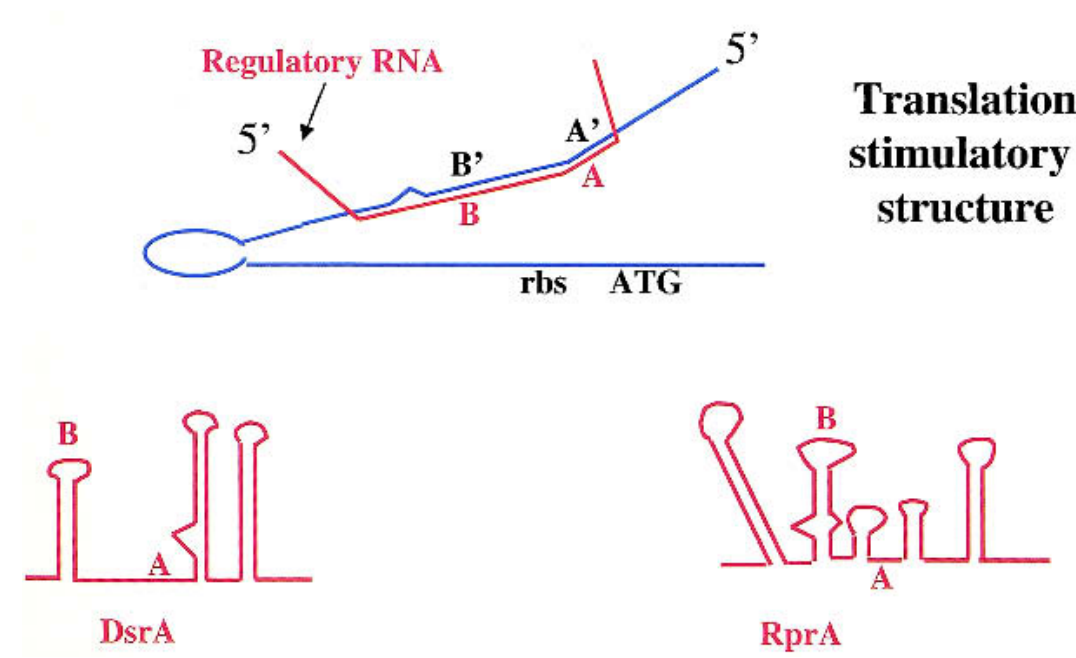

\section{Translation inhibitory structure}


puter, region B would again be in a loop (Fig. 3) that could initiate pairing with the corresponding rpoS stem loop. DsrA can also negatively regulate the synthesis of hns, another pleiotropic regulator in E. coli; in this case, RNA structure-probing experiments implicate interactions between DsrA and hns RNA that include the second stemloop of DsrA (Lease and Belfort 2000). A parallel case of positive regulation of translation by disruption of an inhibitory hairpin is the stimulation of synthesis of a virulence factor, $\alpha$-toxin, by RNA III in Staphylococcus aureus (Morfeldt et al. 1995). As with DsrA, RNA III is thought to also negatively regulate expression of other genes.

Spot 42 RNA regulates polarity within the gal operon of E. coli by down-regulating translation of the third gene in the operon, galK (Moller et al. 2002b). Complementarity between Spot 42 RNA and an extended region both upstream and downstream of the galK translational start codon exist, involving $>60 \mathrm{nt}$ of the 109-nt small RNA, potentially making 44 base pairing interactions with the target mRNA. Changes in nuclease protection patterns for this whole region upon addition of galK RNA confirm this extensive interaction (Moller et al. 2002b). Thus far, no information is available from mutagenesis studies to address the relative importance of all of these complementary regions or whether interaction initiates with a shorter kissing complex. The longest complementary patch of $10 \mathrm{bp}$ includes those sequences in the first loop of the small RNA.

The initial interactions of a fifth E. coli regulatory RNA, RyhB, have not been determined. However, this small RNA can simultaneously down-regulate at least six different messenger RNAs (Massé and Gottesman 2002). In at least five of these cases, regions of complementarity are found between RyhB and the message sequence just upstream of the start of translation. In addition, many of the target genes have long, conserved 5' UTRs, suggesting the possibility of secondary structures in the message that might affect the interaction with RyhB or consequences of that interaction. Message is rapidly degraded after RyhB synthesis is turned on for all of these targets. Whether message degradation is the primary effect or is secondary to a block in translation is not yet known.

For eukaryotic small regulatory RNAs, such as the small temporal RNAs identified as developmental regulators in C. elegans, the 22-nt RNA is processed from a larger fold-back precursor (for review, see Grosshans and Slack 2002). In the case of the two first such small temporal RNAs to be found, let-7 and lin-4 in C. elegans, multiple complementary sequences have been identified in the 3' UTR of their target mRNAs (Lee et al. 1993; Wightman et al. 1993; Reinhart et al. 2000). Base pairing with the target is incomplete, giving no more than $6 \mathrm{bp}$ of pairing in a row, but extends over $\sim 17-18$ of the $22 \mathrm{bp}$. Very little is known currently about how these small RNAs are presented to their targets in vivo. Because an interaction with the $3^{\prime}$ UTR is used to inhibit translation, the microRNAs must act on fully transcribed messages, unlike some of the plasmid examples discussed above. How this $3^{\prime}$ UTR interaction results in translation inhibition is not yet known, but presumably at some point there is interaction of the $3^{\prime}$ UTR with the $5^{\prime}$ of the message as well (Grosshans and Slack 2002).

The other major small RNA species in eukaryotes with similarities to the regulatory RNAs discussed above is RNAi. These double-stranded RNAs are also processed from longer, double-stranded precursors, frequently from exogenous sources (infecting viruses, for instance); the same RNAse III-like enzyme that processes the microRNAs has been implicated in RNAi maturation (Grishok et al. 2001). The consequence of the formation of 22-nt double-stranded RNAs is the degradation of the homologous target message. Thus, RNAi operates to destroy double-stranded viral RNAs and RNAs from some repeated sequences that result in double-stranded transcripts. It is not yet clear what differentiates a double-stranded RNA precursor from maturing into a double-stranded RNAi or the single stranded microRNA, or, once mature, why RNAi but not microRNAs lead to target mRNA destruction. The length of the exact match between small RNA and target (longer for RNAi than for the microRNAs) has been suggested as a possible critical difference. If so, stems in the microRNA stem-loop precursors must also contain information to direct the specific and asymmetric loss of one arm of the stem after processing. Thus far, RNAi acts primarily as a host defense mechanism for viral RNA and transposon invaders, rather than a natural regulatory process, although evidence for a role of the RNAi pathway in silencing repeat sequences during Drosophila development has been found (Aravin et al. 2001). Any process that results in synthesis of an antisense message should promote silencing of the sense message via RNAi. Recently, antisense messages from within genes have been implicated in RNAi-like silencing of heterochromatin (Reinhart and Bartel 2002; Volpe et al. 2002).

\section{How is small RNA activity regulated?}

For any regulatory system, one must understand not only the details of how one part works on another, but where the possibility of regulation-of introducing a response to an environmental or cellular signal lies. Is the regulatory RNA always expressed at one level, and the output is simply the result of that steady-state level? If so, why use such a regulator? If not, what can change to turn the regulatory signal on and then to turn it back off? Does regulation depend solely on the amount of the small RNA, or do other factors modulate RNA use? If amounts of the small RNA are critical, then the triggers/ regulatory signals that govern amounts-both synthesis and stability-are where the regulatory logic lies.

If amounts are not the whole answer, how does the modulation operate-to change binding constants or the competition between different pairing partners, or by changing the activity of the regulatory RNAs in other ways? The potential of RNA structures to directly sense environmental cues is provided by two examples that are 
not believed to involve small RNAs. The thermometer for regulating the synthesis of the heat-shock $\sigma$ factor of $E$. coli has been shown to depend on the melting characteristics of the $\sigma$ factor messenger RNA, including the 5' UTR and sequences within the coding region (Morita et al. 1999); other such RNA thermosensors have been described in Rhizobium (Nocker et al. 2001; Johansson et al. 2002). RNAs may also be able to interact with small molecules; conserved sequences in the 5' UTRs of various genes involved in vitamin biosynthesis have been proposed to regulate translation initiation or transcription termination, as the antisense RNAs do, apparently by directly binding small molecules (adenosylcobalamin in one case, thiamin in another; Nou and Kadner 2000; Miranda-Rios et al. 2001; Stormo and Ji 2001). No examples of regulatory RNAs regulated by small molecule binding have yet been described.

For the plasmid replication control systems, the biological aim is to keep copy number constant. Thus, the transcription of the regulatory RNA and its activity level is set at a steady-state that gives an appropriate copy number; an unstable regulatory RNA and/or regulation that is not absolutely tight assures a window for plasmid replication. If copy number rises, so does the copy number of the gene encoding the antisense RNA. Little evidence for natural regulation of synthesis, degradation, or interaction has been described.

The RNA-regulated toxin-antitoxin systems such as that encoded by plasmid R1 kill host cells when the plasmid is lost. Steady-state levels of both antisense and target RNAs are sufficient to keep toxin synthesis entirely off when the plasmid is still present in the cell. In this case, the regulatory signal is loss of plasmid DNA, leading to a halt in new RNA synthesis. Because the antisense regulatory RNA is more unstable than the target message, antisense RNA degradation serves as a timer for cell death. Thus, the transcription of the antitoxin must have stopped long enough for it to decay to a level less than that of the usually less-abundant toxin, a safety check for the cell not to kill itself during any brief stop in transcription (Fig. 2; Gerdes et al. 1997). Such a timer also requires that the action of the antisense RNA be fully reversible, and that it be susceptible to degradation when complexed with its target (or it comes on and off briefly). In fact, this timer is the second of two in this system; the first is provided by the necessity for a slow $3^{\prime}$ exonucleolytic processing of the message for it to be active for either translation or antisense RNA action (Gerdes et al. 1997). These characteristics, necessary for appropriate regulation, may be unique to this system.

For the bacterial small RNAs, it is clear that the major level of regulation is the regulated transcription of the small RNA (Table 3). In contrast to the plasmid antisense molecules, the bacterial regulatory RNAs are usually under tight and specific regulation. Thus, the regulatory signaling cascades can be as complex and varied as the transcriptional regulation that has been studied in these organisms for many years. OxyS is synthesized only when OxyR is activated by oxidative stress, and is synthesized divergently from OxyR itself (Altuvia et al.
1997). Spot 42 is negatively regulated by cAMP and CRP (Moller et al. 2002b). It has been known for many years that polarity in the gal operon was regulated by cAMP and CRP, but only recognized recently that this is via the regulation of spot 42 synthesis by CRP, coupled with the role of spot 42 in polarity regulation (Moller et al. 2002b). It is hard to imagine a more efficient way to down-regulate translation of a single gene within an operon under a given condition; almost every other polarity mechanism that we know of either operates in a way that depends on upstream synthesis or is set at a constant level by termination and translation signals within the operon that are not easily perturbed by environmental signals, or requires a dedicated antitermination protein. It remains to be seen how widespread this particular use of regulatory RNAs is. Because the polarity in this case is solely at the protein level, it will not be visible on microarrays and may not be appreciated except in particularly well-studied operons.

DsrA, a positive regulator of RpoS translation, is synthesized at higher amounts at low temperatures; it is only under these conditions that RpoS synthesis becomes DsrA-dependent (Sledjeski et al. 1996; Repoila and Gottesman 2001). The second small RNA positive regulator of RpoS, RprA, is synthesized under the control of a phospho-relay system responsive to cell surface stress, RcsC/RcsB. RpoS synthesis increases in an RprAdependent fashion when this phospho-relay is activated (Majdalani et al. 2002). However, there is some evidence of regulation, not yet understood, at the level of activity of the small RNAs on the RpoS message; under osmotic stress, RpoS synthesis increases in a DsrA-dependent fashion although the initial level of DsrA is not sufficient to stimulate RpoS synthesis and DsrA synthesis does not appear to increase under these conditions (Majdalani et al. 2001).

RyhB is repressed by the Fur repressor and is barely detectable when Fe is abundant, but levels of the RNA rise rapidly after iron depletion. Only when iron is limiting are the targets of RyhB decreased in expression (Massé and Gottesman 2002). It was noted in the genomic searches for novel small RNAs that many of them showed distinct expression patterns, presumably linked, once we know what they do, to their activities (Argaman et al. 2001; Wassarman et al. 2001).

Regulation of small RNA synthesis also seems to be critical for the eukaryotic microRNAs with roles in development. The transcripts for lin-4 and let-7 are only detected at the stage in development in those cells in which regulation of targets takes place. Many, but not all, of the other newly found microRNAs are also found only at given stages of development. Because these small RNAs must also be processed to be active, processing and localization could be additional steps for regulation, but there is no evidence of this thus far (Grosshans and Slack 2002).

Whenever levels of the regulatory molecule are critical for regulation, it follows that not only synthesis, but degradation or inactivation should be important in regulating function. This remains a puzzle with many small 
RNAs. Whereas the plasmid-encoded small RNAs almost always have the short half-lives expected if levels of synthesis are important, that is not the case for the bacterial small RNAs. This anomaly suggests that there is an aspect of RNA use and turnover not being captured by current experiments-for instance, the functional rather than the chemical half-life of these small RNAs has not been determined. The necessity for turning off the system could, in principle, be absent for a developmental cascade like the C. elegans development pathway in which small RNAs have been found to act. If the role of these RNAs is to turn off a message once it is no longer needed, synthesis of the small RNA at the appropriate stage may be sufficient; the target messages may not be needed again during the life of that organism. Whereas small regulatory RNAs in bacteria do seem associated with developmental cascades such as the induction of stationary phase in E. coli, such developmental cascades can sometimes be reversed within a short time, requiring a more active recovery method than dilution of the small RNA with cell growth.

\section{What does the future hold? Evaluating our anti-stealth measures}

Small RNAs are likely to continue to emerge as central regulators in both prokaryotes and eukaryotes. What have we learned thus far that can help us integrate them into our understanding of how cells respond to changing environments and undergo development? (1) Intergenic regions are not simply spacers. Particularly when we can detect conservation for a region of no clear function, we should suspect either small RNAs, or their targets, 5' and 3' UTRs. Methods for detecting small RNAs should continue to improve, once we know what to search for. (a) Regulatory RNAs may, in principle, be made from within genes, either from the antisense strand, presumably to target the sense strand, or processed from within a coding region. Examples from plasmid antisense regulators suggest that there may be significant constraints on RNA structure, stability, and activity, which make direct pairing with a target mRNA coding region difficult to evolve. (b) Computational approaches have been most successful in prokaryotes; direct isolation of sized RNAs has been most successful in eukaryotes. Neither approach is likely to identify everything. (2) Outcomes of antisense pairing cover the full range of possible RNA functions. By changing the RNA folding of the target RNA, transcription termination, translation, and mRNA degradation can all be perturbed. Positive regulators, as well as negative regulators, have been found, and should be expected. (a) Because pairing of regulatory RNAs and their targets can be for short stretches, computer predictions of possible targets are not always useful, and may only predict some of the actual range of targets. (b) Pairing in which the outcome is changes in message levels may be analyzed with microarrays; those in which the outcome is a change in translation will require proteomic approaches. (3) The primary level of regulation thus far detected is in the synthesis of the small RNAs.
Therefore, understanding when they are made may give us our best hint as to why they are made. How systems shut down after induction ceases remains largely unexplored. (4) When a signal and a regulatory outcome exist, but the link between signal and outcome is puzzling, we should at least consider the possibility of a stealthy small RNA regulator. Understanding how cAMP regulated polarity in the gal operon required the realization that spot 42 RNA, regulated by cAMP, was down-regulating translation within the operon (Moller et al. 2002b). Positive regulation of a set of genes in E. coli by Fur and Fe was not understood until RyhB RNA was shown to be negatively regulated by Fur and negatively regulate these same genes (Massé and Gottesman 2002). Regulation of RpoS translation was known to be under the control of an upstream hairpin, but the role of small regulatory RNAs in opening this hairpin was not immediately apparent (Brown and Elliott 1997).

Why use a regulatory RNA, rather than a traditional transcriptional regulator or a regulator of protein activity or stability? A priori, we would imagine that a small RNA that regulates translation costs the cell more than regulating message before it is made, but less than energy-dependent degradation of a protein once it is made. The RNA itself is small and can be quickly made available once its synthesis starts. Therefore, we can imagine that regulatory RNAs can lead to rapid inhibition or stimulation of translation in response to a signal. Of course, regulation via a small RNA may, and frequently is, in addition to regulation at the level of transcription and protein activity and stability. If the aim is simply to add an extra layer of regulation to other regulatory circuits, having it carried out at the level of translation by a small RNA requires little extra work from the cell. Beyond that, we can only extrapolate from the few cases we think we understand. For plasmid copy-number regulation and regulation of polarity, RNA regulators may be the simplest means to the desired regulation. Plasmids either use antisense RNAs or DNA sites to regulate copy number (del Solar et al. 1998); the abundance of both should vary directly with copy number, and either can exist in parallel, but highly specific forms for closely related plasmids that may coexist in cells. Discoordinate and regulated expression of different genes within an operon is hard to achieve; most natural polarity does not change ratios of different products with conditions. By introducing an independently regulated small RNA, regulated polarity can occur, as it does in the gal operon. In a number of other examples from E. coli, the regulatory RNA allows genes under disparate transcriptional regulation to be coregulated at a post-transcriptional step. Possibly using separate regulation at two different steps is easier to evolve than integrating an additional component into different and already complex promoters. Finally, the RNA regulators might be simply the remnants of ancient, pre-DNA and pre-protein control systems (Joyce 2002), although it is clear that they are not as fully conserved across kingdoms as are ribosomal and tRNAs.

This field has advanced at an astonishing rate over 
the last few years, and shows little sign of slowing down. Nevertheless, it seems likely to be quite a while before we can fully describe how even a few of these small RNAs act to reprogram and fine-tune cellular growth.

\section{Acknowledgments}

I thank David Fitzgerald, Gisela Storz, Nadim Majdalani, Eric Massé, Francis Repoila, and members of my laboratory for discussions and comments on the manuscript.

\section{References}

Abo, T., Inada, T., Ogawa, K., and Aiba, H. 2000. SsrA-mediated tagging and proteolysis of LacI and its role in the regulation of lac operon. EMBO J. 19: 3762-3769.

Altuvia, S., Weinstein-Fischer, D., Zhang, A., Postow, L., and Storz, G. 1997. A small stable RNA induced by oxidative stress: Role as a pleiotropic regulator and antimutator. Cell 90: 43-53.

Altuvia, S., Zhang, A., Argaman, L., Tiwari, A., and Storz, G. 1998. The Escherichia coli oxyS regulatory RNA represses fhlA translation by blocking ribosome binding. EMBO $\mathrm{I}$. 17: 6069-6075.

Aravin, A.A., Naumova, N.M., Tulin, A.V., Vagin, V.V., Rozovsky, Y.M., and Gvozdev, V.A. 2001. Double-stranded RNA-mediated silencing of genomic tandem repeats and transposable elements in the $D$. melanogaster germline. Curr. Biol. 11: 1017-1027.

Argaman, L. and Altuvia, S. 2000. fhlA repression by OxyS RNA: Kissing complex formation at two sites results in a stable antisense-target RNA complex. J. Mol. Biol. 300: 1101-1112.

Argaman, L., Hershberg, R., Vogel, J., Bejerano, G., Wagner, E.G.H., Margalit, H., and Altuvia, S. 2001. Novel small RNA-encoding genes in the intergenic region of Escherichia coli. Curr. Biol. 11: 941-950.

Asano, K. and Mizobuchi, K. 2000. Structural analysis of late intermediate complex formed between plasmid ColIb-P9 Inc RNA and its target RNA. How does a single antisense RNA repress translation of two genes at different rates? J. Biol. Chem. 275: 1269-1274.

Asano, K., Hama, C., Inoue, S.-i., Moriwaki, H., and Mizobuchi, K. 1999. The plasmid ColIb-P9 antisense Inc RNA controls expression of the RepZ replication protein and its positive regulator repY with different mechanisms. J. Biol. Chem. 274: 17924-17933.

Baker, C.S., Morozov, I., Suzuki, K., Romeo, T., and Babitzke, P. 2002. CsrA regulates glycogen biosynthesis by preventing translation of $\operatorname{glgC}$ in Escherichia coli. Mol. Microbiol. 44: 1599-1610.

Blomberg, P., Nordstrom, K., and Wagner, E.G. 1992. Replication control of plasmid R1: RepA synthesis is regulated by CopA RNA through inhibition of leader peptide translation. EMBO J. 11: 2675-2683.

Brantl, S. 2002. Antisense-RNA regulation and RNA interference. Biochim. Biophys. Acta 1575: 15-25.

Brown, L. and Elliott, T. 1997. Mutations that increase expression of the rpoS gene and decrease its dependence on $h f q$ function in Salmonella typhimurium. J. Bacteriol. 179: 656662.

Chen, C., Sheng, S., Shao, Z., and Guo, P. 2000. A dimer as a building block in assembling RNA. A hexamer that gears bacterial virus phi29 DNA-translocating machinery. J. Biol. Chem. 275: 17510-17516.

Chen, S., Lesnik, E.A., Hall, T.A., Sampath, R., Griffey, R.H., Ecker, D.J., and Blyn, L.B. 2002. A bioinformatics based approach to discover small RNA genes in the Escherichia coli genome. Biosystems 65: 157-177.

del Solar, G., Giraldo, R., Ruiz-Echevarria, M.J., Espinosa, M., and Diaz-Orejas, R. 1998. Replication and control of circular bacterial plasmids. Microbiol. Mol. Biol. Rev. 62: 434-464.

Devereux, J., Haeberli, P., and Smithies, O. 1984. A comprehensive set of sequence analysis programs for the VAX. Nucleic Acids Res. 12: 387-395.

Eddy, S.R. 2001. Non-coding RNA genes and the modern RNA world. Nat. Rev. Genet. 2: 919-920.

- 2002. Computational genomics of noncoding RNA genes. Cell 109: 137-140.

Eguchi, Y., Itoh, T., and Tomizawa, J. 1991. Antisense RNA. Annu. Rev. Biochem. 60: 631-652.

Engelberg-Kulka, H. and Glaser, G. 1999. Addiction modules and programmed cell death and antideath in bacterial cultures. Annu. Rev. Microbiol. 53: 43-70.

Franch, T., Petersen, M., Wagner, E.G.H., Jacobsen, J.P., and Gerdes, K. 1999a. Antisense RNA regulation in prokaryotes: Rapid RNA/RNA interaction facilitated by a general U-turn loop structure. J. Mol. Biol. 294: 1115-1125.

Franch, T., Thisted, T., and Gerdes, K. 1999b. Ribonuclease III processing of coaxially stacked RNA helices. J. Biol. Chem. 274: 26572-26578.

Gerdes, K., Gultyaev, A.P., Franch, T., Pedersen, K., and Mikkelsen, N.D. 1997. Antisense RNA-regulated programmed cell death. Annu. Rev. Genet. 31: 1-31.

Gillet, R. and Felden, B. 2001. Emerging views on tmRNA-mediated protein tagging and ribosome rescue. Moc. Microbiol. 42: $879-885$.

Gottesman, S., Roche, E., Zhou, Y.-N., and Sauer, R.T. 1998. The ClpXP and ClpAP proteases degrade proteins with carboxy-terminal peptide tails added by the SsrA-tagging system. Genes \& Dev. 12: 1338-1347.

Gottesman, S., Storz, G., Rosenow, C., Majdalani, N., Repoila, F., and Wassarman, K.M. 2001. Small RNA regulators of translation: Mechanisms of action and approaches for identifying new small RNAs. Cold Spring Harbor Symp. Quant. Biol. 66: 353-362.

Greenfield, T.J., Franch, T., Gerdes, K., and Weaver, K.E. 2001. Antisense RNA regulation of the par post-segregational killing system: Structural analysis and mechanism of binding of the antisense RNA, RNAII and its target, RNAI. Mol. Microbiol. 42: 527-537.

Grishok, A., Pasquinelli, A.E., Conte, D., Li, N., Parrish, S., Ha, I., Baillie, D.L., Fire, A., Ruvkun, G., and Mello, C.C. 2001. Genes and mechanisms related to RNA interference regulate expression of the small temporal RNAs that control $C$. elegans developmental timing. Cell 106: 23-34.

Grosshans, H. and Slack, F.J. 2002. Micro-RNAs: Small is plentiful. J. Cell Biol. 156: 17-21.

Gudapaty, S., Suzuki, K., Wang, X., Babitzke, P., and Romeo, T. 2001. Regulatory interactions of Csr components: The RNA binding protein CsrA activates $\operatorname{csr} B$ transcription in Escherichia coli. J. Bacteriol. 183: 6017-6027.

Heinrich, J., Velleman, M., and Schuster, H. 1995. The tripartite immunity system of phages P1 and P7. FEMS Microbiol. Rev. 17: 121-126.

Henkin, T.M. 1996. Control of transcription termination in prokaryotes. Annu. Rev. Genet. 30: 35-57.

Herman, C., Thevenet, D., Bouloc, P., Walker, G.C., and D'Ari, R. 1998. Degradation of carboxy-terminal-tagged cytoplsmic 
proteins by the Escherichia coli protease HflB (FtsH). Genes \& Dev. 12: 1348-1355.

Huttenhofer, A., Kiefmann, M., Meier-Ewert, S., O'Brien, J., Lehrach, H., Bachellerie, J.-P., and Brosius, J. 2001. RNomics: An experimental approach that identifies 201 candidates for novel, small, non-messenger RNAs in mouse. EMBO $J$. 20: 2943-2953.

Johansson, J., Mandin, P., Renzoni, A., Chiaruttini, C., Springer, M., and Cossart, P. 2002. An RNA thermosensor controls expression of virulence genes in Listeria monocytogenes. Cell 110: 551-561.

Joyce, G.F. 2002. The antiquity of RNA-based evolution. Nature 418: $214-221$.

Karzai, A., Roche, E.D., and Sauer, R.T. 2000. The SsrA-SmpB system for protein tagging, directed degradation and ribosome rescue. Nat. Struct. Biol. 7: 449-455.

Keiler, K.C., Waller, P.R.H., and Sauer, R.T. 1996. Role of a peptide tagging system in degradation of proteins synthesized from damaged messenger RNA. Science 271: 990-993.

Kiss, T. 2002. Small nucleolar RNAs: An abundant group of noncoding RNAs with diverse cellular functions. Cell 109: $145-148$.

Klein, R.J., Misulovin, Z., and Eddy, S.R. 2002. Noncoding RNA genes identified in AT-rich hyperthermophiles. Proc. Natl. Acad. Sci. 99: 7542-7547.

Lagos-Quintana, M., Rauhut, R., Lendeckel, W., and Tuschl, T. 2001. Identification of novel genes coding for small expressed RNAs. Science 294: 853-858.

Lagos-Quintana, M., Rauhut, R., Yalcin, A., Meyer, J., Lendeckel, W., and Tuschl, T. 2002. Identification of tissue-specific microRNAs from mouse. Curr. Biol. 12: 735-739.

Lau, N.C., Lim, L.P., Weinstein, E.G., and Bartel, D.P. 2001. An abundant class of RNAs with probable regulatory roles in Caenorhabditis elegans. Science 294: 858-862.

Lease, R.A. and Belfort, M. 2000. A trans-acting RNA as a control switch in Escherichia coli: DsrA modulates function by forming alternative structures. Proc. Nat1. Acad. Sci. 97: 9919-9924.

Lee, R.C. and Ambros, V. 2001. An extensive class of small RNAs in Caenorhabditis elegans. Science 294: 862-864.

Lee, R.C., Feinbaum, R.L., and Ambros, V. 1993. The C. elegans heterochronic gene lin-4 encodes small RNAs with antisense complementarity to lin-14. Cell 75: 843-854.

Lindqvist, B.H., Deho, G., and Calendar, R. 1993. Mechanisms of genome propagation and helper exploitation by satellite phage P4. Microbiol. Rev. 57: 683-702.

Majdalani, N., Cunning, C., Sledjeski, D., Elliott, T., and Gottesman, S. 1998. DsrA RNA regulates translation of RpoS message by an anti-antisense mechanism, independent of its action as an antisilencer of transcription. Proc. Natl. Acad. Sci. 95: 12462-12467.

Majdalani, N., Chen, S., Murrow, J., St. John, K., and Gottesman, S. 2001. Regulation of RpoS by a novel small RNA: The characterization of RprA. Mol. Microbiol. 39: 1382-1394.

Majdalani, N., Hernandez, D., and Gottesman, S. 2002. Regulation and mode of action of RprA, a small RNA that stimulates RpoS translation. Mol. Microbiol. 46: (In press).

Malmgren, C., Wagner, E.G.H., Ehresmann, C., Ehresmann, B., and Romby, P. 1997. Antisense RNA control of plasmid R1 replication. The dominant product of the antisense RNAmRNA binding is not a full RNA duplex. I. Biol. Chem. 272: $12508-12512$.

Massé, E. and Gottesman, S. 2002. A small RNA regulates the expression of genes involved in iron metabolism in Escherichia coli. Proc. Natl. Acad. Sci. 99: 4620-4625.
Miranda-Rios, J., Navarro, M., and Soberon, M. 2001. A conserved RNA structure (thi box) is involved in regulation of thiamin biosynthetic gene expression in bacteria. Proc. Nat1. Acad. Sci. 98: 9736-9741.

Moller, T., Franch, T., Hojrup, P., Keene, D.R., Bachinger, H.P., Brennan, R., and Valentin-Hansen, P. 2002a. Hfq: A bacterial Sm-like protein that mediates RNA-RNA interaction. Mol. Cell 9: 23-30.

Moller, T., Franch, T., Udesen, C., Gerdes, K., and ValentinHansen, P. 2002b. Spot 42 RNA mediates discoordinate expression of the E. coli galactose operon. Genes \& Dev. 16: 1696-1706.

Morfeldt, E., Taylor, D., von Gabain, A., and Arvidson, S. 1995. Activation of alpha-toxin translation in Staphylococcus aureus by the trans-encoded antisense RNA, RNAIII. EMBO I. 14: 4569-4577.

Morita, M.T., Tanaka, Y., Kodama, T.S., Kyoguoku, Y., Yanagi, H., and Yura, T. 1999. Translational induction of heat shock transcription factor $\sigma^{32}$ : Evidence for a built-in RNA thermosensor. Genes \& Dev. 13: 655-665.

Mourelatos, Z., Dostie, J., Paushkin, S., Sharma, A., Charroux, B., Abel, L., Rappsilber, J., Mann, M., and Dreyfuss, G. 2002. miRNAPs: A novel class of ribonucleoproteins containing numerous microRNAs. Genes \& Dev. 16: 720-778.

Nocker, A., Hausherr, T., Balsiger, S., Krstulovic, N.-P., Hennecke, H., and Narberhaus, F. 2001. A mRNA-based thermosensor controls expression of rhizobial heat shock genes. Nucleic Acids Res. 29: 4800-4807.

Nou, X. and Kadner, R.J. 2000. Adenosylcobalamin inhibits ribosome binding to btuB RNA. Proc. Natl. Acad. Sci. 97: 7190-7195.

Novick, R.P., Iordanescu, S., Projan, S.J., Kornblum, J., and Edelman, I. 1989. pT181 plasmid replication is regulated by a countertranscript-driven transcriptional attenuator. Cell 59: 395-404.

Reinhart, B.J. and Bartel, D.P. 2002. Small RNAs correspond to centromere heterochromatic repeats. Science 297: 1831.

Reinhart, B.J., Slack, F.J., Basson, M., Pasquinelli, A.E., Bettinger, J.C., Rougvie, A.E., Horvitz, H.R., and Ruvkun, G. 2000. The 21-nucleotide let-7 RNA regulates developmental timing in Caenorhabditis elegans. Nature 403: 901-906.

Reinhart, B.J., Weinstein, E.G., Rhoades, M.W., Bartel, B., and Bartel, D.P. 2002. MicroRNAs in plants. Genes \& Dev. 16: $1616-1626$.

Repoila, F. and Gottesman, S. 2001. Signal transduction cascade for regulation of RpoS: Temperature regulation of DsrA. I. Bacteriol. 183: 4012-4023.

Rivas, E., Klein, R.J., Jones, T.A., and Eddy, S.R. 2001. Computational identification of noncoding RNAs in E. coli by comparative genomics. Curr. Biol. 11: 1369-1373.

Romeo, T. 1998. Global regulation by the small RNA-binding protein CsrA and the non-coding RNA molecule CsrB. Mol. Microbiol. 29: 1321-1330.

Schattner, P. 2002. Searching for RNA genes using base-composition statistics. Nucleic Acids Res. 30: 2076-2082.

Schumacher, M.A., Pearson, R.F., Moller, T., Valentin-Hansen, P., and Brennan, R.G. 2002. Structures of the pleiotropic translational regulator Hfq and an Hfq-RNA complex: A bacterial Sm-like protein. EMBO J. 21: 3546-3556.

Siemering, K.R., Praszkier, J., and Pittard, A.J. 1994. Mechanism of binding of the antisense and target RNAs involved in the regulation of IncB plasmid replication. I. Bacteriol. 176: $2677-2688$.

Sledjeski, D.D., Gupta, A., and Gottesman, S. 1996. The small RNA, DsrA, is essential for the low temperature expression 
of RpoS during exponential growth in Escherichia coli. EMBO J. 15: 3993-4000.

Sledjeski, D.D., Whitman, C., and Zhang, A. 2001. Hfq is necessary for regulation by the untranslated RNA DsrA. I. Bacteriol. 183: 1997-2005.

Stormo, G.D. and Ji, Y. 2001. Do mRNAs act as direct sensors of small molecules to control their expression? Proc. Natl. Acad. Sci. 98: 9465-9467.

Storz, G. 2002. An expanding universe of noncoding RNAs. Science 296: 1260-1263.

Suzuki, K., Wang, X., Weilbacher, T., Pernestig, A.K., Melefors, O., Georgellis, D., Babitzke, P., and Romeo, T. 2002. Regulatory circuitry of the CsrA/CsrB and BarA/UvrY systems of Escherichia coli. J. Bacteriol. 184: 5130-5140.

Tang, T.-H., Bachellerie, J.-P., Rozhdestvensky, T., Bortolin, M.-L., Huber, H., Drungowski, M., Elge, T., Brosius, J., and Huttenhofer, A. 2002. Identification of 86 candidates for small non-messenger RNAs from the archaeon Archaeoglobus fulgidus. Proc. Natl. Acad. Sci. 99: 7536-7541.

Tjaden, B., Saxena, R.M., Stolyar, S., Haynor, D.R., Kolker, E., and Rosenow, C. 2002. Transcriptome analysis of Escherichia coli using high density oligonucleotide probe arrays. Nucleic Acids Res. 30: 3732-3738.

Tomizawa, J. and Som, T. 1984. Control of ColE1 plasmid replication: Enhancement of binding of RNA to the primer transcript by the Rom protein. Cell 38: 871-878.

Ueda, K., Yamamoto, Y., Ogawa, K., Abo, T., Inokuchi, H., and Aiba, H. 2002. Bacterial SsrA system plays a role in coping with unwanted translational readthrough caused by suppressor tRNAs. Genes Cells 7: 509-519.

Volpe, T.A., Kidner, C., Hall, I.M., Teng, G., Grewal, S.I.S., and Martienssen, R.A 2002. Regulation of heterochromatic silencing and histone H3 lysine-9 methylation by RNAi. Science 297: 1833-1837.

Wagner, E.G.H. and Brantl, S. 1998. Kissing and RNA stability in antisense control of plasmid replication. Trends Biochem. Sci. 23: 451-454.

Wagner, E.G.H. and Simons, R.W. 1994. Antisense RNA control in bacteria, phages, and plasmids. Annu. Rev. Microbiol. 48: $713-742$.

Wassarman, K.M. 2002. Small RNAs in bacteria: Diverse regulators of gene expression in response to environmental changes. Cell 109: 141-144.

Wassarman, K.M. and Storz, G. 2000. 6S RNA regulates E. coli RNA polymerase activity. Cell 101: 613-623.

Wassarman, K.M., Zhang, A., and Storz, G. 1999. Small RNAs in Escherichia coli. Trends Microbiol. 7: 37-45.

Wassarman, K.M., Repoila, F., Rosenow, C., Storz, G., and Gottesman, S. 2001. Identification of novel small RNAs using comparative genomics and microarrays. Genes \& Dev. 15: $1637-1651$.

Wightman, B., Ha, I., and Ruvkun, G. 1993. Posttranscriptional regulation of the heterochronic gene lin-14 by lin- 4 mediates temporal pattern formation in C. elegans. Cell 75: 855-862.

Wilson, I.W., Praszkier, J., and Pittard, A.J. 1994. Molecular analysis of RNAI control of repB translation in IncB plasmids. J. Bacteriol. 176: 6497-6508.

Zeiler, B.N. and Simons, R.W. 1996. Control by Antisense RNA. In Regulation of gene expression in Escherichia coli. (eds. E.C.C. Lin and A.S. Lynch), pp. 67-83. R.G. Landes Co., Austin, TX.

Zhang, A., Wassarman, K.M., Ortega, J., Steven, A.C., and Storz, G. 2002. The Sm-like Hfa protein increases OxyS RNA interaction with target mRNAs. Mol. Cell 9: 11-22. 


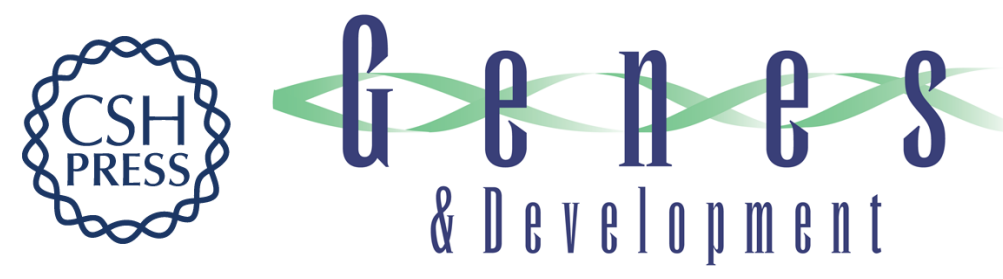

\section{Stealth regulation: biological circuits with small RNA switches}

Susan Gottesman

Genes Dev. 2002, 16:

Access the most recent version at doi:10.1101/gad.1030302

References This article cites 86 articles, 41 of which can be accessed free at: http://genesdev.cshlp.org/content/16/22/2829.full.html\#ref-list-1

License

Email Alerting Receive free email alerts when new articles cite this article - sign up in the box at the top Service right corner of the article or click here.

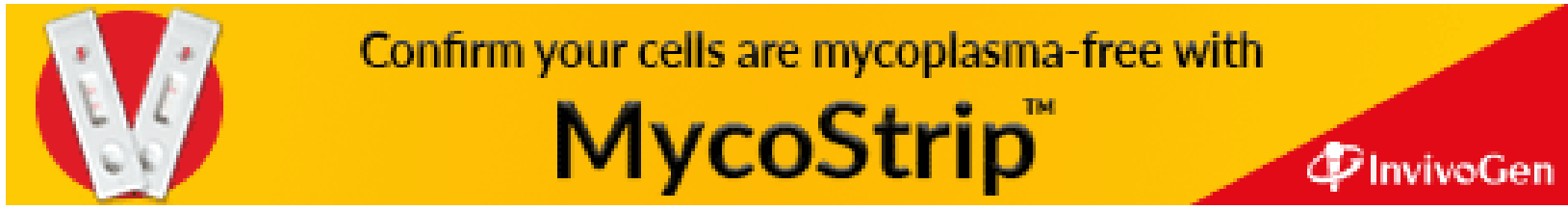

